\title{
Pengobatan Alternatif Sebagai Upaya Penyembuhan Penyakit
}

\author{
Dwi Ayu Andira \\ Magister Psikologi Sains, Fakultas Psikologi, Universitas Surabaya \\ ayuandira.dwi@gmail.com \\ Jatie K. Pudjibudojo \\ Magister Psikologi Sains, Fakultas Psikologi, Universitas Surabaya
}

\begin{abstract}
In modern times, variety of advanced technologies have been present in various fields, one of which is health. Rapid developments in the health sector include medical care. Medical treatment experiences a lot of progress that give hope for the patient's recovery. This certainty is because medical treatment has been considered a rational and scientific treatment. On the other hand, in reality there are still many patients who use alternative medicine. Patients have trust or believe that alternative medicine is a treatment that can healing their illness because they have economical prices, minimal side effects and are easy to find. The purpose of this literature study is to find out the reasons for patients in choosing alternative medicine as an effort to healing the disease. So that alternative medicine is chosen by patients to try to healing diseases other than using medical treatment.
\end{abstract}

Keywords : alternative medicine; trust; healing.

\begin{abstract}
Abstrak
Pada zaman modern sekarang, telah hadir berbagai macam teknologi canggih diberbagai bidang, salah satunya bidang kesehatan. Perkembangan pesat pada bidang kesehatan antara lain terlihat dari pengobatan medis. Pengobatan medis mengalami banyak kemajuan yang seolah memberikan harapan bagi kesembuhan pasien. Kepastian tersebut dikarenakan pengobatan medis telah dianggap sebagai pengobatan yang rasional dan ilmiah. Disisi lain, pada kenyataannya masih banyak pasien yang menggunakan pengobatan alternatif. Pasien memiliki trust atau percaya bahwa pengobatan alternatif merupakan pengobatan yang dapat menyembuhkan penyakitnya dikarenakan memiliki harga yang ekonomis, minim efek samping dan mudah ditemukan. Tujuan dari studi literatur ini adalah untuk mengetahui alasan pasien dalam memilih pengobatan alternatif sebagai upaya penyembuhan penyakitnya. Sehingga pengobatan alternatif dipilih oleh pasien untuk upaya penyembuhan penyakit selain menggunakan pengobatan medis.
\end{abstract}

Kata kunci : pengobatan alternative; trust; penyembuhan. 


\section{Pendahuluan}

Menurut World Health Organization (WHO), kesehatan adalah kondisi yang lengkap baik fisik, mental, sosial yang bebas dari penyakit atau kelemahan. Pengertian kesehatan menurut Undang-Undang Nomor 36 Pasal 1 Tahun 2019 adalah keadaan sehat baik secara fisik, mental, spiritual maupun sosial yang memungkinkan setiap orang untuk hidup produktif secara sosial dan ekonomi. Kesehatan merupakan suatu hal yang sangat penting bagi kehidupan manusia sehingga ketika kondisi tubuh tidak baik atau kurang sehat maka pasien akan berkunjung ke dokter untuk memperoleh pengobatan medis. Pengobatan medis dipilih karena dianggap sebagai pengobatan rasional dan ilmiah yang dipercaya dapat memberikan kesembuhan kepada pasien. Tentunya dengan harapan pengobatan medis akan menjadikan diri pasien dapat sehat seperti sedia kala atau sembuh dari penyakitnya. Kenyataan yang terjadi pada pasien yaitu pasien menjadi tidak percaya oleh pengobatan medis dikarenakan pasien tidak merasakan adanya kesembuhan yang signifikan (Fanani \& Dewi, 2014). Rayner, McLachlan, Foster \& Cramer (2009) menjelaskan bahwa adanya ketidakpuasan dan hasil yang tidak baik terhadap pengobatan medis. Hal tersebut menyebabkan pasien beralih tidak lagi menggunakan pengobatan medis dan akhirnya memilih dan menggunakan pengobatan alternatif.

Pengobatan alternatif adalah pengobatan non medis dimana peralatan dan bahan yang digunakan tidak termasuk dalam standart pengobatan medis. Pengobatan alternatif tidak dilakukan oleh tenaga kesehatan profesional seperti dokter (Savitri, 2017). National Institute of Health, 2005 (disitat dalam Kamaluddin 2010) menyebutkan bahwa terapi alternatif adalah sekumpulan sistem pengobatan dan perawatan kesehatan, praktek dan produk yang secara umum tidak menjadi bagian dari pengobatan konvensional. Savitri (2017) menjelaskan terdapat macam-macam pengobatan alternatif antara lain akupunktur, bekam, pengobatan aura, obat-obatan herbal dan jamu, reiki, ceragem (pijat batu giok), pijat refleksi, hipnosis, gurah. Selain macam-macam pengobatan alternatif tersebut, pengobatan air juga merupakan bagian dari macam-macam pengobatan alternatif. Wardiani \& Gunawan (2017) menyebutkkan bahwa pengobatan air juga 
menjadi salah satu pengobatan alternatif yang prakteknya masih banyak dilakukan oleh masyarakat. Praktek pengobatan air dilakukan dengan dibacakan doa oleh seorang mursyid sehingga air tersebut dipercaya dapat menyembuhkan penyakit pasien. Ardani (2013) memaparkan dalam penelitiannya bahwa pengobatan alternatif melalui dukun juga masih dipilih banyak pasien. Pasien percaya kepada dukun karena dukun dianggap bisa menyembuhkan penyakit yang dideritanya. Pengobatan alternatif pada dukun bersifat universal sehingga dukun dapat mengobati berbagai jenis penyakit pasien.

Pengobatan alternatif masih banyak dipilih oleh pasien karena harganya yang murah, mudah ditemukan dan manjur (Triratnawati, 2010). Kamaluddin (2010) menjelaskan bahwa pasien memilih menggunakan pengobatan alternatif selain harganya yang murah juga dikarenakan minimnya efek samping yang akan terjadi pada tubuh. Lebih lanjut dijelaskan bahwa pasien ingin terbebas dari efek samping obat yang diperoleh dari pengobatan konvensional. Alasan pasien memilih pengobatan alternatif juga dikarenakan pengobatan alternatif memiliki proses yang sederhana daripada pengobatan medis (Fanani \& Dewi, 2014).

Berdasarkan penjelasan diatas tujuan dari penulisan studi literatur ini adalah untuk mengetahui alasan pasien dalam memilih pengobatan alternatif sebagai upaya penyembuhan penyakitnya dilihat dari tinjauan psikologi. Tulisan ini diharapkan dapat memberikan manfaat bagi pasien bahwa pengobatan alternatif dapat dijadikan referensi selain pengobatan medis sebagai upaya penyembuhan penyakit. Manfaat bagi lingkungan sekitar (keluarga, teman) pasien adalah untuk lebih memberikan semangat kepada pasien untuk tetap menjalani pengobatan dengan baik. Manfaat bagi tenaga medis, diharapkan lebih dekat dengan pasien agar muncul rasa percaya pasien kepada tenaga medis dalam menjalani proses pengobatan, sehingga penyakit dapat disembuhkan.

\section{Pembahasan}

Pengobatan alternatif merupakan salah satu pengobatan yang dapat menyembuhkan penyakit dan sampai sekarang pengobatan alternatif masih banyak dipilih oleh pasien. Fenomena pasien memilih pengobatan alternatif 
banyak dilakukan dengan diawali dari mencoba pengobatan medis. Pemilihan pengobatan medis menjadi pengobatan awal yang dipilih pasien sebelum akhirnya memilih pengobatan alternatif. Hal tersebut dikarenakan pengobatan medis sampai saat ini merupakan pengobatan yang secara pembuktian ilmiah sudah teruji dan menjadi pengobatan yang canggih dengan berbagai ilmu dan alat medisnya. Dalam proses pengobatan medis, tenaga profesional medis akan memeriksan kondisi pasien kemudian memberikan diagnosa kepada pasien mengenai jenis penyakitnya. Setelah itu tenaga profesional akan memberikan obat sesuai dengan diagnosa pasien yang telah ditentukan dalam kurun waktu tertentu sampai kondisi pasien membaik atau dinyatakan sembuh. Kadang kala proses tersebut tidak berjalan dengan baik karena pasien masih belum menerima diagnosa penyakit yang dideritanya (Citra \& Eriany 2015).

Self acceptance atau penerimaan diri memiliki peranan penting bagi pasien dalam upaya penyembuhan penyakitnya. Menurut Sartain dalam Handayani 2000 (dalam Citra \& Eriany 2015) penerimaan diri adalah suatu kemampuan individu untuk menerima diri apa adanya dan mengakui keberadaan dirinya secara objektif. Lebih lanjut dijelaskan bahwa bukan berarti membuat seorang individu kehilangan ambisinya, tetapi individu tersebut tetap mempunyai ambisi dan adanya keinginan untuk memperbaiki keadaan dan mengembangkan dirinya menjadi lebih baik. Feist, Feist \& Roberts (2018) menyatakan bahwa penerimaan diri merupakan bagian teori aktualisasi diri yang dikemukakan oleh Maslow. Penerimaan diri merupakan salah satu nilai dalam 14 nilai-nilai B (nilai-nilai kehidupan). Maslow menyatakan bahwa orang orang yang mengaktualisasikan dirinya dapat menerima diri sendiri apa adanya tanpa perlu bersikap defensive, berpura-pura dan tidak mempunyai perasaa bersalah yang menghancurkan dirinya. Maslow menjelaskan individu yang mempunyai penerimaan diri yang baik memiliki selera yang baik terhadap makanan, tidur dan seks, tidak mengkritik kekurangan diri sendiri dan tidak terbeban oleh kecemasan atau rasa malu yang berlebihan.

Tahapan menuju penerimaan diri menurut Kubler dan Ross dalam Taylor 1999 (dalam Citra \& Eriany 2015) adalah pengingkaran (denial), kemarahan 
(anger), depresi (depression), tawar-menawar (bargain), penerimaan diri (self acceptance). Disaat pasien menerima diagnosa yang telah ditetapkan oleh tenaga profesional medis maka pengingkaran akan muncul. Pasien menjadi tidak percaya akan kondisi yang dialaminya, merasa gugup, merasa cemas sampai pada akhirnya fase pengingkaran masuk ke tahapan selanjutnya yaitu tahapan kemarahan. Pada tahapan kemarahan, pasien merasa akan sangat marah terhadap diagnosa penyakit yang diterimanya. Pasien marah dikarenakan mengapa dirinya yang terkena penyakit tersebut, mengapa bukan orang lain saja. Apakah pasien bisa atau tidak dalam menjalani proses penyakit tersebut. Kemudian beranjak pada tahapan berikutnya yaitu depresi yang merupakan perasaan tak berdaya, perasaan putus asa sehingga menyebabkan munculnya perilaku seperti tidak nafsu makan, sering menangis bahkan perasaan takut jika meninggal dan lain sebagainya. Ketika telah memasuki tahapan depresi maka seiring berjalanannya waktu pasien memasuki tahapan bargain dimana perasaan yang untuk melakukan tawar menawar atau kesepakatan kepada Tuhan. Barulah pasien masuk kedalam tahapan penerimaan diri yaitu menerima dengan baik kondisi yang sedang terjadi, menerima penyakit yang sedang dialaminya.

Ketika pasien memiliki penerimaan diri yang baik bukan berarti membuat pasien pasrah atau tidak ingin melakukan pengobatan apapun, tetapi pasien akan tetap berusaha untuk mendapatkan pengobatan yang baik agar penyakitnya dapat sembuh. Pengobatan medis akan dilanjutkan setelah pasien "berdamai" dengan kondisinya. Pengobatan medis dilanjutkan karena diagnosa dan obat telah diberikan oleh tenaga profesional sehingga perlu untuk diikuti apa-apa yang sudah diberikan. Seiring dengan berjalannya waktu dalam melakukan pengobatan medis, tidak ada perubahan yang signifikan yang dirasakan oleh pasien (Fanani \& Dewi, 2014). Lebih lanjut dijelaskan bahwa kondisi membaik hanya setelah mengkonsumsi obat, beberapa jam setelahnya tubuh menjadi tidak baik. Kamaluddin 2010 menjelaskan bahwa penggunaan obat medis ditakutkan oleh pasien akan menimbulkan efek samping yang tidak baik bagi tubuh. Dampak pada hal ekonomi pun menjadi suatu hal yang dikeluhkan, bahwa biaya pengobatan medis yang mahal tetapi kondisi tubuh tidak kunjung membaik menyebabkan 
pasien enggan menggunakan pengobatan medis dan lebih memilih pengobatan alternatif.

Fenomena ketidakpercayaan pasien kepada pengobatan medis akhirnya membuat pasien beralih kepada pengobatan alternatif. Tentunya, pasien akan memilih pengobatan alternatif yang dirasa cocok untuk kondisi tubuhnya, dikarenakan pengobatan alternatif juga banyak macamnya. Pemilihan pengobatan alternatif banyak dilakukan seperti mendapatkan informasi dari lingkungan sekitar seperti keluarga, teman untuk memilih suatu pengobatan alternatif yang cocok bagi kondisi pasien (Kamaluddin, 2010). Dijelaskan lebih lanjut bahwa informasi pengobatan alternatif dari lingkungan sekitar dapat dipercaya oleh pasien. Pengobatan alternatif juga merupakan suatu pengobatan yang telah digunakan sejak zaman dahulu oleh nenek moyang dan hal tersebut dipercaya didalam masyarakat secara turun menurun. Hal serupa juga dijelaskan oleh Fanani \& Dewi (2014) bahwa pengobatan alternatif sudah sering dipilih dan dilakukan oleh keluarga sejak dahulu.

Pasien percaya terhadap pengobatan alternatif yang disarankan oleh lingkungan sekitar ini sesuai dengan pengertian trust atau percaya yang dikemukakan oleh Chen 2010 (dalam Putri 2017) bahwa kepercayaan adalah kondisi psikologis yang terdiri atas niat untuk menerima kerentanan berdasarkan harapan positif mengenai niat atau perilaku orang lain tanpa adanya kemampuan untuk memantau atau mengontrol pihak lain. Mayer, Davis dan Schoorman (1995) menjelaskan bahwa kepercayaan adalah kesediaan satu pihak untuk memercayai pihak lainnya berdasarkan harapan pihak lain akan melakukan tindakan tertentu yang penting bagi pihak yang memercayainya. Ketika pasien percaya akan pengobatan alternatif yang sudah disarankan oleh lingkungan sekitarnya, maka pasien akan memilih dan menggunakan pengobatan alternatif sebagai upaya penyembuhan penyakit.

Mayer, Davis dan Schoorman (1995) menyatakan bahwa trust memiliki beberapa dimensi yaitu ability (kemampuan), benevolence (kebaikan hati) dan integrity (integritas). Ability (kemampuan) memiliki definisi dimana trustor (orang yang memberikan kepercayaan) memiliki kemampuan dapat memengaruhi 
trustee (orang yang diberi kepercayaan). Kompetensi, pengalaman, kemampuan dalam ilmu pengetahuan juga merupakan hal yang melingkupi definisi ability. Dalam hal ini lingkungan sekitar pasien berperan sebagai trustor yang memiliki kemampuan untuk memengaruhi pasien yang berperan sebagai trustee untuk memilih pengobatan alternatif. Pasien memilih pengobatan alternatif atas pengaruh dari lingkungan sekitar seperti keluarga. Fanani \& Dewi (2014) menjelaskan bahwa pasien beralih dari pengobatan medis ke pengobatan alternatif karena ajakan keluarga. Keluarga sudah lama menggunakan pengobatan alternatif sehingga pasien mengikutinya. Kamaluddin (2010), juga menyatakan bahwa pasien memilih pengobatan alternatif dikarenakan saran dan dukungan dari keluarga dan pengalaman orang lain yang sudah mencoba pengobatan alternatif.

Dimensi kedua yaitu benevolence (kebaikan hati) merupakan hal terbaik yang diberikan trustor kepada trustee yang terlepas dari motif egosentris. Dalam hal ini orang yang keluarga, teman dan orang lain memiliki kemampuan untuk memberikan pemahaman, informasi terkait pengobatan alternatif kepada pasien. Hal tersebut sesuai dengan penelitian yang dilakukan oleh Kamaluddin (2010), bahwa keluarga pasien melakukan diskusi terkait pengobatan alternatif kepada pasien. Keluarga tidak hanya memberikan saran, tetapi juga memberikan waktu dan tenaganya untuk berdiskusi dengan pasien. Triratnawati (2010) menjelaskan bahwa keluarga yang berperan sebagai trustor mau untuk "turun tangan" dalam memberikan pengobatan alternatif kepada pasien seperti membelikan jamu.

Integritas (integrity) menjadi dimensi ketiga, dimana memiliki pengertian trustee akan menjalankan apa-apa yang sudah disampaikan oleh trustor dengan tujuan trustee dapat melakukan secara baik apa yang telah diinformasikan. Trustor akan memberikan segala informasi, fakta kepada trustee. Dalam hal pengobatan altenatif ini, pasien akan diberikan informasi, fakta oleh keluarga, teman dan orang lain dengan harapan pasien akan mengikuti informasi tersebut. Wardiani dan Gunawan (2017) menyatakan bahwa pengobatan air yang dilakukan oleh jamaah di Pesantren Suryalaya Pagerageung Tasikmalaya memiliki jamaah ratusan bahkan ribuan yang datang dengan membawa botol berisi air dari rumah agar didoakan oleh mursyid. Hal tersebut memiliki makna bahwa jamaah yang 
mendatangi pesantren telah melakukan secara baik informasi yang diberikan oleh orang di lingkungan sekitarnya untuk melakukan pengobatan alternatif.

\section{Kesimpulan}

Pengobatan alternatif merupakan pengobatan yang dapat dilakukan untuk menyembuhkan penyakit. Pengobatan alternatif dipiliih pasien untuk menyembuhkan penyakitnya karena harganya yang ekonomis, minim efek samping dan mudah ditemukan. Penerimaan diri yang baik dari pasien akan menjadikan pasien berusaha untuk mencari pengobatan yang baik untuk kesembuhannya. Pasien memilih dan menggunakan pengobatan alternatif dikarenakan pasien percaya bahwa pengobatan tersebut dapat menyembuhkan penyakitnya. Selanjutnya, saran untuk pasien yang menggunakan pengobatan alternatif, agar tetap memeriksakan kesehatan kepada tenaga medis atau tenaga kesehatan yang profesional, supaya kesehatan tubuh dapat terpantau dengan baik. Saran bagi peneliti selanjutnya diharapkan meneliti tentang individu yang melakukan pengobatan alternatif dari tinjauan hardiness dan dukungan sosial.

\section{DAFTAR PUSTAKA}

Ardani, I. (2013). Eksistensi Dukun dalam Era Dokter Spesialis. Lakon: Jurnal Kajian Sastra dan Budaya. Vol 1 (2) : 28-33.

Citra, L. R. A. \& Eriany, P. (2015). Penerimaan Diri pada Remaja Puteri Penderita Lupus. Psikodimensia. Vol 14 (1) : 67-86.

Fanani, S \& Dewi, T. K. (2014). Health Belief Model pada Pasien Pengobatan Alternatif Supranatural dengan Bantuan Dukun. Jurnal Psikologi Klinis dan Kesehatan Mental. Vol 3 (1) : 54-59.

Feist, J., Feist, G.J \& Roberts, T.A. (2018). Theories of Personality, Eighth Edition. Alih Bahasa : R. A. Hadwitia Dewi Pertiwi. Jakarta : Salemba Humanika.

Kamaluddin, R. (2010). Pertimbangan dan Alasan Pasien Hipertensi Menjalani Terapi Alternatif Komplementer Bekam di Kabupaten Banyumas. Jurnal Keperawatan Soedirman. Vol 5 (2) : 95-104. 
Mayer, R. C., Davis, J. H. \& Schoorman, F. D. (1995). An Integrative Mode of Organizational Trust. Academy of Management Review. Vol 20 (3) : 709734.

Putri, N. A. (2017). Kepercayaan (Trust) Masyarakat Suku Dayak Benuaq pada Pengobatan Tradisional Belian. Psikoborneo. Vol 5 (3) : 620-629.

Rayner, J. A., McLachlan, H. L., Foster, D. A \& Cramer, R. (2009). Australian Women's Use of Complementary and Alternative Medicines to Enhance Fertility: Exploring The Experiences of Women and Practitioners. BMC Complementary and Alternative Medicine, 9:52.

Savitri, T. (2017). Kenapa Tidak Boleh Memprioritaskan Pengobatan Alternatif Daripada Pergi ke Dokter. (On-line). Diambil pada tanggal 22 Februari 2019 dari https://hellosehat.com/hidup-sehat/tips-sehat/apakahpengobatan-alternatif-aman/

Triratnawati, A. (2010). Pengobatan Tradisional, Upaya Meminimalkan Biaya Kesehatan Masyarakat Desa di Jawa. Jurnal Manajemen Pelayanan Kesehatan. Vol 13 (2) : 69-73.

Undang-undang Republik Indonesia Nomor 36 Tahun 2009 Tentang Kesehatan. (2009). (Versi Elektronik). Diambil pada tanggal 11 April 2019 dari http://www.depkes.go.id/

resources/download/general/UU\%20Nomor\%2036\%20Tahun2\%20009\% 20tentang \% 20 Kesehatan.pdf

Wardiani, S. R \& Gunawan, D. (2017). Aktualisasi Budaya Terapi Air Sebagai Media Pengobatan Oleh Jamaah di Pesantren Suryalaya Pagerageung Tasikmalaya. Jurnal Aplikasi Ipteks untuk Masyarakat. Vol 6 (1) : 33-39.

World Health Organization. WHO Definition of Health. Diambil pada tanggal 11 April 2019 dari https://www.who.int/about/who-we-are/constitution. 